\title{
CHEMICAL AND MINERALOGICAL ANALYSIS OF HIGH- PURITY QUARTZ FROM NEW DEPOSITS IN A GREEK ISLAND, FOR POTENTIAL EXPLORATION
}

\author{
Georgios Charalampides \\ Department of Mineral Resources Engineering ${ }^{1}$ \\ Konstantinos Vatalis \\ Department of Mineral Resources Engineering ${ }^{1}$ \\ Apostolos Baklavaridis \\ Department of Mineral Resources Engineering ${ }^{1}$ \\ Vayos Karayannis \\ Department of Chemical Engineering ${ }^{1}$ \\ vkarayannis@uowm.gr \\ Nikolas-Ploutarch Benetis \\ Department of Chemical Engineering ${ }^{1}$ \\ ${ }^{1}$ University of Western Macedonia \\ Koila, Kozani, Greece, 50100
}

\begin{abstract}
The current study presents an original chemical, elemental and mineralogical characterization of new quartz mineral deposits situated in Ios island, Cyclades, Aegean sea, Greece, via X-Ray Diffraction (XRD), Scanning Electron Microscopy with Energy Dispersive Spectroscopy (SEM-EDS) and Inductively Coupled Plasma Mass Spectrometry (ICP-MS) trace-element analysis.

Actually, the mineral Quartz (crystalline $\mathrm{SiO}_{2}$ ) is found in nature in varying quality and is explored and traded for use in different applications of significant importance depending on the quartz purity.

The results of the thorough chemical and mineralogical analysis indicate that quartz originating from the location examined in this research is almost free from other microcrystalline phases, and therefore it can be characterized as highly pure $\alpha$-quartz.

Thus, it can be used in the industry of ultra-high purity quartz production for specific applications, as long as the deposits are exploitable. In this framework, a preliminary estimation of the economic benefits from a potential exploration versus the environmental aspects of mining, taking into account sustainability issues in the region, is provided highlighting the local social needs.

Keywords: Quartz, crystalline $\mathrm{SiO}_{2}$, chemical, mineralogical, analysis, XRD, SEM-EDS, ICP-MS, high purity $\alpha$-quartz, new mineral deposit, Greek island, exploration.
\end{abstract}

\section{Introduction}

Quartz is the second, after feldspar, most abundant mineral in the Earth's continental crust. The reduction of silica solubility in some hydrothermal fluids in appropriate geological environments is the main cause for the formation of quartz deposition. As such environments could be mentioned the alpine-type fissures, quartz veins crosscutting related mainly to granitoids, skarns as well as volcanic rocks altered by epithermal activity of Tertiary age $[1,2]$.

The different geological environments and thereafter different conditions such as temperature and pressure determine in general the type of quartz mineral which should be formed. Moreover, the environment of deposition is largely determined often by the habit and the type of the crystals, the paragenesis and accessory minerals and the solid inclusions they might contain $[3,4]$.

Large-scale detachments in specific areas of Hellenic mountain belt (e. g. Cyclades island complex) have been formed during a post-orogenic episode, which revealed metamorphic core 
complexes in a back-arc setting. It is worth mentioning that the Cenozoic magmatic activity is considered to be a result from under-thrusting of the African plate beneath the Eurasian plate [5].

Quartz mineral is found in nature in varying purities and forms and is commercially traded in various qualities for several industrial applications. High value-added products such as silicon wafers, photovoltaic panels and optical glass as well as ordinary materials like foundry sand for metal casting or filler for adhesives and grouts are included [6-9].

Quartz deposits have been found in many regions in Greece [10,11]. Particularly, in the southern part of the island of Ios, there is a quartz occurrence with a width of $30-50 \mathrm{~m}$. The reserves of this occurrence are estimated at 150,000 tons. A second deposit of about $80 \mathrm{~m}$ in length and a width varying from 2 to $10 \mathrm{~m}$ is located approx. $500 \mathrm{~m}$ south of the former site. The reserves of this deposit are estimated at 50,000 tons. The third appearance is in the Kefalas location west of previous appearances. In this position until 1940 there was a quarry activity and the present reserves are estimated to only 20,000 tons. Also, in the wider area of Agia and in the villages of Kastri-Prinias and Amigdali in the Larissa area, Region of Thessaly, Greece a total of four significant quartz occurrences have been identified, with enough iron oxides. Total reserves are estimated at approximately 1,760,000 tons [12]. Moreover, at a distance of about $50 \mathrm{~km} \mathrm{NE}$ of Thessaloniki, near the village Asseros, there is a quartz deposit at Kastri, where a quarry previously operated. The remaining reserves are estimated at about 100,000 tons and are hosted between post-volcanic deposits of gneiss, mica and schist. In addition, in Korfoula area, $5 \mathrm{~km}$ southwest of Leptokarya, prefecture of Evros, Region of Thrace, Greece, there are two large quartz occurrences. In both cases, the form of the quartz material is fine-crystalline with a minor amount of iron. The total amount of the reserves is estimated at about 1,130,000 tons [13].

In 2011, a total of 8,210 tons of quartz products were produced from the region of Thessaloniki and Kilkis. Out of this production, about $20 \%$ was exported. The rest was consumed by domestic ceramics or glass industry, for the production of sanitary ware and porcelain, as well as glass products (e. g. Vitruvit, Ionia Porcelain, Jiula and others, with about 1,500 tons each). At the same year (2011), the LAVA quarry, which is located $12 \mathrm{~km}$ south of Adamas (port of Milos island, Cyclades Complex), was operated for last time, with a capacity of 120,000 tons/year. From this quarry, two grades were produced, high purity SSL10 (whiteness $>80 \%$ ) and SSL20 (pink color), with differences in $\mathrm{SiO}_{2}$ content and various impurities, mainly $\mathrm{Fe}_{2} \mathrm{O}_{3}$. The production of the two aforementioned regions, due to the great crisis of the Greek cement industry was stopped [14].

Summarizing, in addition to the above, also very important occurrences are found in Lavrio and Penteli (Attiki), Soufli (Thrace), Petsofas (Lesvos), Avysallos (Serifos), Meliti (Florina, Western Macedonia), and lately Ios island (Cyclades islands, Aegean sea, Greece). The occurrence of quartz in the aforementioned places may have different forms and colors and other properties.

In the present study, the quality of the deposits in the later region (Ios island) was thoroughly characterized by employing advanced analytical methods. Moreover, potential economic benefits from future exploration of the deposits intended for specific applications were evaluated also taking into account environmental aspects of mining in the region.

\section{Geological settings}

In Ios Island, which belongs to Cyclades island complex, Southern Aegean, quartz was found in different rock occurrences. The investigated samples were detected as quartz lenses in the Central and the Southwestern part of the island within a gneiss-complex of quartz-albite gneiss and garnet-mica schist as well in metamorphosed intrusive bodies. In particular, site (a) consists mainly of granite and mica schist which have probably been formed during the last stages of the transformation process. In site (b) the quartz was found in chlorite and mica schist. Site (c) was dominated by a gneiss shale, sometimes with albite, muscovite and quartz crystals. The gneiss schist probably derives genetically from one gneiss penetration which was transformed during the process into a mica and gneiss state. There are alternating shale layers with dolomite - calcite marbles, with their lively red color of which is due to the possible presence hematite. In site (d) quartz was a constituent of a pigmatic vein possibly inside the mica. 


\section{Sampling methodology}

The sampling positions of the quartz deposits in Ios island are shown in the map provided in Fig. 1 and are summarized in Table 1. A detailed description of each sampling position is given in Fig. 2. Specifically:

The "Profitis Elias" site (position 1) is located approximately $3 \mathrm{~km}$ east of the Hora of the island at altitude $520 \mathrm{~m}$. It consists mainly of granite and mica schist which have probably been formed during the last stages of transformation. Within these specified slates scattered appearances milky quartz were observed, just below the church of Prophitis Elias. The second sampling site (position 2) is located in the broader area of Profitis Elias approximately $2.5 \mathrm{~km} \mathrm{NE}$ of the church. Milky quartz lenses of variable size ranging from a few $\mathrm{cm}$ to several $\mathrm{m}$ were formed within chlorite and mica schist. The third sampling site (position 3) is located at the "Hill Kefalas" at altitude $360 \mathrm{~m}$. The position is geologically dominated by gneiss shale, sometimes with albite, muscovite and quartz crystals. The gneiss schist probably derives genetically from one gneiss penetration which was transformed during the process into a mica and gneiss state. There are alternating shale layers with dolomite - calcite marbles, with their lively red color of which is due to the possible presence hematite. Except for the presence of quartz within the converted shale slate in the form of lenses, underpins and as micro-veins with thickness ranging from a few $\mathrm{cm}$ and length up to $2 \mathrm{~m}$ into the body of the shale. There are also a few spots inside the quartz occurrences, which may be due to the presence of hematite. The last sampling site (position 4) "Manganari" is situated approximately $5 \mathrm{~km}$ north of Manganari in the southern mountainous part of Ios island. Dispersed appearances of white quartz lenses, as a constituent of a pigmatic vein possibly inside the mica shale were observed. The red accents of quartz exist possibly due to the presence of iron oxide inclusions.

The sampling was mainly done from quartz lenses located inside the shales of the deposits by non-eroded and non-altered surface samples.

Since quartz deposits are natural formations and the quantities and composition of the elements can vary, three (3) samples were taken from each of the aforementioned sampling positions and average values are reported in the results for each separate deposit.

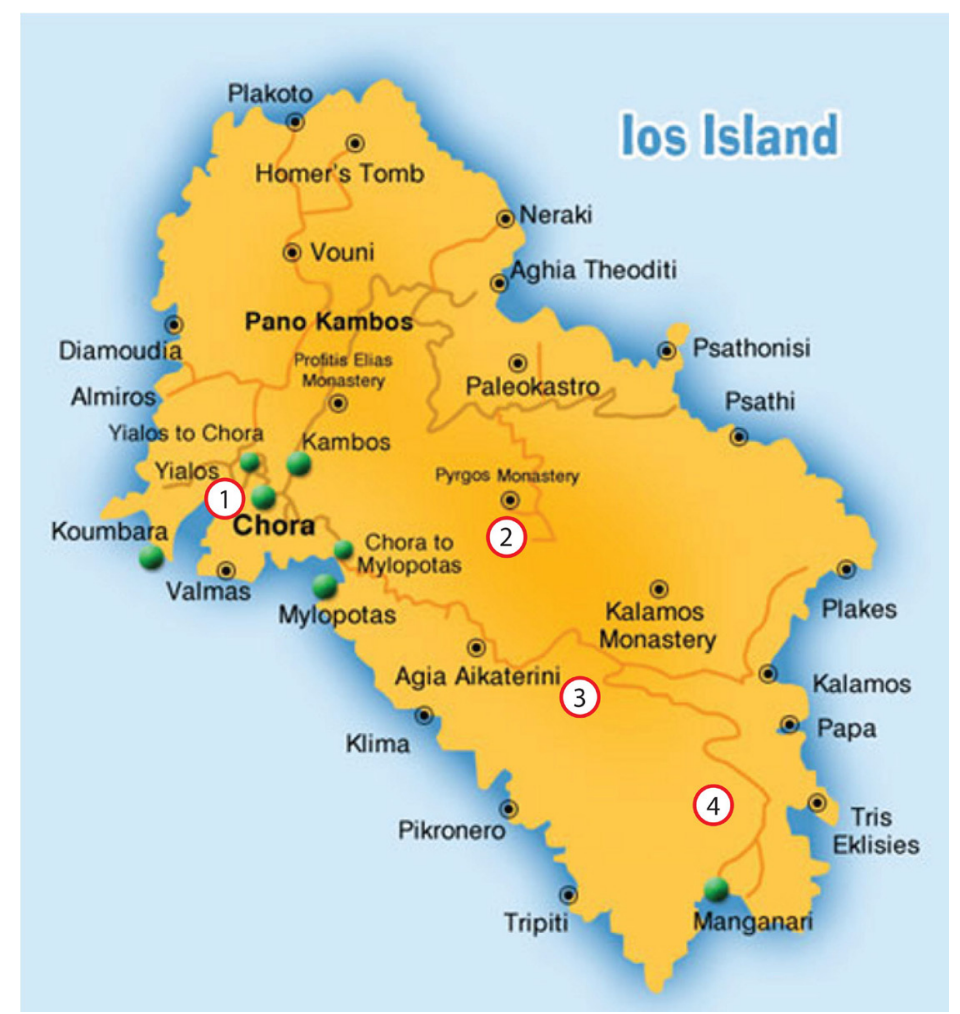

Fig. 1. Numbering of the four sampling sites of the quartz occurrences in Ios island 
Table 1

Sampling areas, positions and sample names

\begin{tabular}{ccc}
\hline Area & Position & Sample Name \\
\hline \multirow{2}{*}{ Ios island } & 1 & Q1-IOS \\
& 2 & Q2-IOS \\
& 3 & Q3-IOS \\
\end{tabular}

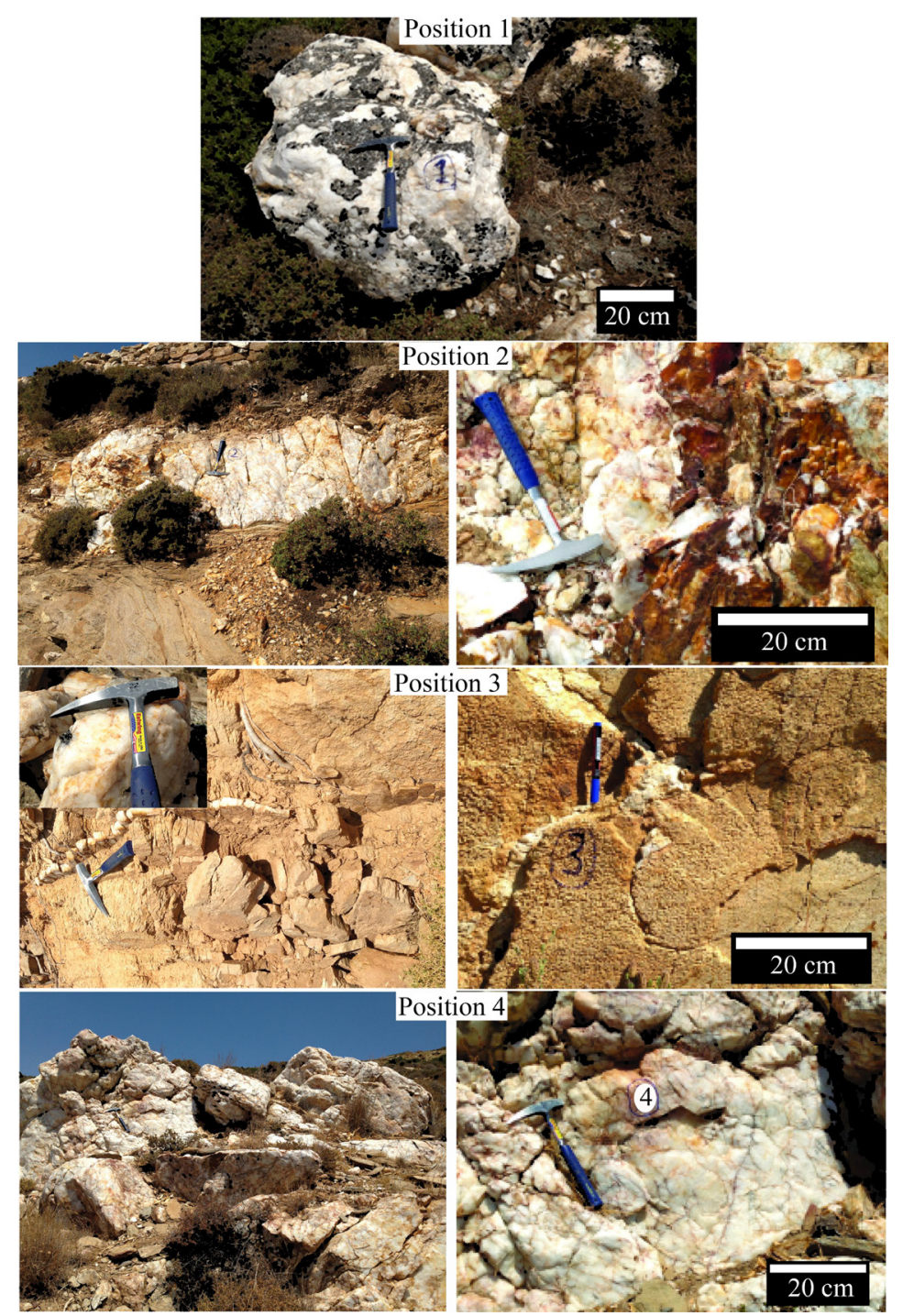

Fig. 2. The sampling positions in Ios island

\section{Characterization Methods}

X-Ray Diffraction (XRD) was carried out in order to identify the mineralogical phases which are present in the quartz samples. In order to conduct the XRD measurements, the quartz samples were mechanically crushed and sieved through a $45 \mu \mathrm{m}$ stainless steel sieve to obtain fine powder. XRD analysis was performed, using a 3003 TT Rich. Seifert Diffractometer (Ni filtered, $\mathrm{Cu} \mathrm{K}=1.54050 \AA)$. The $2 \theta$ scan range varied from $5^{\circ}$ to $80^{\circ}$. Phase identification and quantification was performed by matching the acquired with the COD-AMCSD database. The phase identification and the XRD measurement procedure includes-approximate instrumental error $2 \mathrm{wt} \%$, regarding the phase composition. The crystallite size was estimated using the Scherrer equation: 


$$
D=\frac{K \lambda}{\beta \cos \theta},
$$

where $D$ is the crystallites' size (nm), $K$ is the crystal shape factor which was be taken as $0.9, \lambda$ is the wavelength of the X-ray radiation $(0.154050 \mathrm{~nm}), \beta$ is the full width at half maximum (FWHM), and $\theta$ is the peak position of the XRD pattern.

Morphological and elemental examination was conducted by means of Scanning Electron Microscopy (SEM), using a JEOL 6610LV [15]. The elemental analysis was carried out using an X-Max 80 (Oxford Instruments) Energy Dispersive Spectroscopy (EDS) detector attached to the SEM. Images, elements maps and spectra were acquired and analysed using AZtech Nanoanalysis software. SEM examination was carried out after the samples were coated with carbon in order to eliminate charging under the electron beam.

Trace-element chemical analysis was conducted by inductively coupled plasma mass spectrometry (ICP-MS). A Perkin Elmer ELAN 6100 ICP-MS device was used for the trace-element detection in the quartz samples. The standard deviation of the SEM-EDS and ICP-MS measurements was calculated via the manufacturer's software. The XRD and SEM-EDS measurements were contacted at the Laboratory of Applied Geochemistry, University of Western Macedonia, Greece, while trace elements of selected samples were analyzed by means of ICP-MS at Lithos Laboratory, Institute of Geology and Mineral Exploration (IGME), Greece.

\section{Results and Discussion}

\section{1. Sample Analysis}

The XRD patterns of the samples that are given in Fig. 3 exhibit the characteristic distinct peaks that correspond uniquely to crystalline quartz. Specifically, the peaks of the highest intensity at $20.9^{\circ}, 26.6^{\circ}, 50.1^{\circ}$ and $59.95^{\circ} 2 \theta$ correspond to hkl configurations (100), (101), (112) and (121) respectively, indicating pure mineralogical phase of $\alpha$-quartz. However, in the case of the sample from position 2 (Q2-IOS), the peak around $30^{\circ}$ may be attributed to the presence of calcite $\left(\mathrm{CaCO}_{3}\right)$. Moreover, the minor peaks observed below $20^{\circ}$ for the sample originating from position 3 (Q3-IOS) may be attributed to the presence of iron oxides $\left(\mathrm{Fe}_{2} \mathrm{O}_{3}\right.$ and $\left.\mathrm{Fe}_{3} \mathrm{O}_{4}\right)$ and some clay mineral phases. The presence of iron oxides alongside with the quartz phase is also supported with our observations at position 3 (redish color of the rock - Fig. 2). The crystallite sizes (in $\mathrm{nm}$ ) for all samples are listed in Table 2 and range between 66 and $77 \mathrm{~nm}$.

\section{Table 2}

The crystal size of all samples calculated from equation (1)

\begin{tabular}{cc}
\hline Sample Name & Crystallite size (nm) \\
\hline Q1-IOS & 77 \\
Q2-IOS & 66 \\
Q3-IOS & 67 \\
Q4-IOS & 77
\end{tabular}

SEM-EDS analysis was performed in order to gain insights into the main elements of the investigated mineral samples. In Fig. 4, the SEM-EDS results of Q3 sample are shown, indicative of Ios island. The chemical EDS analyses of the primary elements in the mineral quartz samples are collected in Table 2, where the elemental compositions of all samples are expressed in both wt \% and in atomic composition at \%. The EDS spectrum denotes the presence of only Si and O. The computed $\mathrm{Si}: \mathrm{O}=1: 2$ atomic ratio composition of the sample corresponds exactly to pure silicon oxide $\left(\mathrm{SiO}_{2}\right)$. Furthermore, on the right side of Fig. 4 an elemental map of $\mathrm{Si}$ and $\mathrm{O}$ is shown. Si and O appear to be evenly distributed on the surface of the sample, which indicates the absence of other major inclusions of impurities at the resolution of the scan. The same observations seem to hold true for the rest of the Ios Island's samples. 


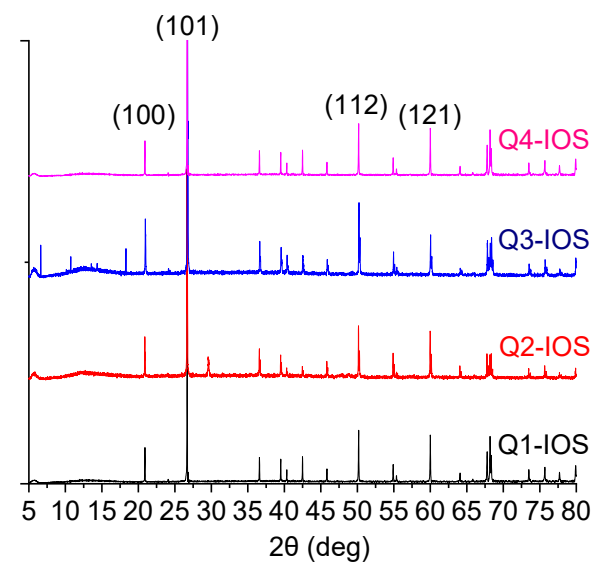

Fig. 3. XRD patterns of the four samples from Ios island examined in this study

Nevertheless, the ICP-MS trace element analysis results (Table 4) reveal the presence of five trace-elements ( $\mathrm{Li}, \mathrm{Na}, \mathrm{Al}, \mathrm{K}, \mathrm{Fe}$ ) in the quartz samples examined. The Q1 sample exhibited the higher trace-element concentrations. Loss of Ignition (\% LOI) results for all samples was quite low (lower than $0.25 \%$ ) as expected for quartz mineral. The analyses results are in good agreement with the related literature $[16,17]$. According to Table 3, Ios island samples seem to be mostly contaminated by $\mathrm{Al}$ and $\mathrm{K}$. Nevertheless, the contaminations of the samples have totally different chemical/mineralogical composition than silica, which, in a planned industrial exploration, could be easily separated from the useful crystalline $\mathrm{SiO}_{2}$ content. It is further worth noting that the aforementioned trace elements that were revealed from the ICP-MS analysis had not been detected by SEM-EDS analysis. This should be attributed to the relatively restricted detection limits of the EDS technique, which remain at $>0.6 \%$ wt.

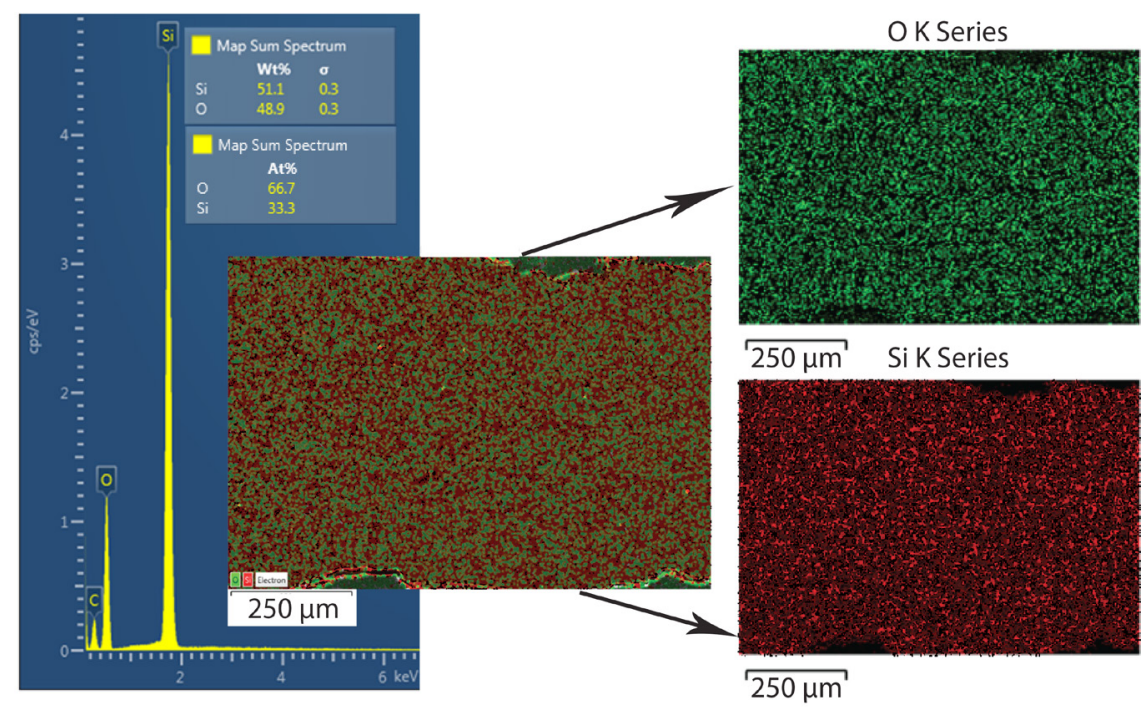

Fig. 4. SEM-EDS analysis and elemental mapping of the main chemical elements $\mathrm{Si}$ and $\mathrm{O}$ of the quartz sample Q3-IOS taken from Ios island (position 3)

The high purity quartz can be classified in four distinct categories, shown in Table $\mathbf{5}$. Based on the results presented (especially Table 4), the quartz minerals from Ios island can rather be characterized as of "low-grade" high purity quartz, as minor elements concentrations of these samples generally lie between 100 and $500 \mathrm{ppm}$. The Q1-IOS sample has the lowest purity, and therefore would be considered for use only as semiconductor filler, LCD and optical glass. The quartz found in Ios may also be used in civil engineering applications and constructions $[2,4]$. Nevertheless, raw quartz can be further purified in order to produce 
quartz with higher purity [18]. In that sense, an application-field broadening of the raw quartz may be achieved [19].

Table 3

EDS results for all samples investigated. The standard deviation is indicated

\begin{tabular}{ccccc}
\hline \multirow{2}{*}{ Sample Name } & \multicolumn{2}{c}{ Elemental composition in wt \% } & \multicolumn{2}{c}{ Elemental composition in at \% } \\
\cline { 2 - 5 } & $\mathbf{S i}$ & $\mathbf{O}$ & $\mathbf{S i}$ & $\mathbf{0}$ \\
\hline Q1-IOS & $53.2 \pm 0.3$ & $46.8 \pm 0.3$ & $33.3 \pm 0.4$ & $66.7 \pm 0.4$ \\
Q2-IOS & $50.9 \pm 0.3$ & $49.1 \pm 0.3$ & $33.3 \pm 0.4$ & $66.7 \pm 0.4$ \\
Q3-IOS & $51.1 \pm 0.3$ & $48.9 \pm 0.3$ & $33.3 \pm 0.4$ & $66.7 \pm 0.4$ \\
Q4-IOS & $56.9 \pm 0.4$ & $43.1 \pm 0.4$ & $33.3 \pm 0.4$ & $66.7 \pm 0.4$
\end{tabular}

Table 4

ICP-MS trace-element analysis and Loss on Ignition (LOI \%) results

\begin{tabular}{|c|c|c|c|c|c|c|}
\hline \multirow{2}{*}{ Sample Name } & \multicolumn{5}{|c|}{ mg/kg (ppm) } & \multirow{2}{*}{ LOI \% } \\
\hline & $\mathbf{L i}$ & $\mathbf{N a}$ & Al & $\mathbf{K}$ & $\mathbf{F e}$ & \\
\hline Q1-IOS & $1.0 \pm 0.02$ & $<20 \pm 0.35$ & $1265 \pm 72$ & $280 \pm 4$ & $155 \pm 2$ & 0.10 \\
\hline Q2-IOS & $0.7 \pm 0.02$ & $<20 \pm 0.35$ & $1082 \pm 51$ & $192 \pm 3$ & $158 \pm 2$ & 0.18 \\
\hline Q3-IOS & $0.5 \pm 0.01$ & $<20 \pm 0.36$ & $355 \pm 6$ & $205 \pm 3$ & $165 \pm 2$ & 0.24 \\
\hline Q4-IOS & $1.1 \pm 0.02$ & $<20 \pm 0.35$ & $542 \pm 8$ & $263 \pm 4$ & $154 \pm 2$ & 0.11 \\
\hline
\end{tabular}

Table 5

Typical quartz types (found in the market) and their typical composition (Götze and Möckel, 2012)

\begin{tabular}{cccc}
\hline Type or application & $\mathbf{S i O}_{2}$ minimum (wt \%) & $\begin{array}{c}\text { Other elements } \\
\text { (maximum wt \%) }\end{array}$ & $\begin{array}{c}\text { Other elements } \\
\text { (maximum ppm) }\end{array}$ \\
\hline Semiconductor filler, LCD and optical glass & 99.8 & 0.2 & 2000 \\
'Lower grade' high purity quartz & 99.95 & 0.05 & 500 \\
'Medium grade' high purity quartz & 99.99 & 0.01 & 100 \\
'High grade' high purity quartz & 99.997 & 0.003 & 30
\end{tabular}

\section{Preliminary economic estimation}

The price and the market size of quartz may vary significantly depending on the purity of the mineral and the concentration of the trace elements that might be present in the final mineral product $[8,18]$. The price and the market size of each type of quartz are summarized in Table 5. It is worth noting that all types of quartz are mined by the open pit method. However, the processing degree of the different types of quartz is a function of the needs and specifications of various consumers [9]. The quartz market is quite large and profitable [10], as shown in Table 6. 'High grade' high purity quartz is rather rare in nature and it is concentrated in minor deposits. Hence, the typical price of 'High grade' high purity quartz is considerably high. In the other types of quartz mineral, with decreasing quartz purity, the market size increases but at the same time the price decreases accordingly. The different types of high purity quartz are mainly destined to solar cells, semiconductors, telecommunications, high temperature lamp tubing, fused quartz crucibles and other highend technological applications. Nevertheless, quartz of lower purity may be used semiconductor filler, LCD (Liquid-Crystal Display) and optical glass. Quartz and high purity quartz may also be used as raw materials for the production of several other materials such as silicon metal (Si) and silicon tetrachloride $\left(\mathrm{SiCl}_{4}\right)$. It is worth mentioning that $\mathrm{Si}$ price is approximately $300 \$ /$ ton, while the price of $\mathrm{SiCl}_{4}$ is $740 \$ /$ ton $[8,18]$.

In Greece, the total annual raw quartz production is approximately 15000 tons. The largest part of the Greek quartz is exported abroad in order to be used in civil engineering applications. The price of the exported Greek quartz is relatively low, 35 \$/ton. The total quartz consumption for 
thirteen Greek ceramic and glass industries is around 80000 tons, while very limited quartz quantities are used in more advanced technological applications (i. e. solar cells, semiconductors etc). To our best knowledge, only two Greek companies, ELVIOR SA and METE SA are mining, processing and commercializing Greek quartz deposits. Specifically, ELVIOR SA is exploiting the quartz deposits of Thessaloniki, Kilkis and Chalkidiki, while METE SA is exploiting the quartz deposits in Florina.

Table 6

Price and market size of each type/application of quartz

\begin{tabular}{ccc}
\hline Type or application & Market Size (Mtons/year) & Typical Price (\$/tonne) \\
\hline Semiconductor filler, LCD and optical glass & 2 & 150 \\
'Lower grade' high purity quartz & 0.75 & 300 \\
'Medium grade' high purity quartz & 0.25 & 500 \\
'High grade' high purity quartz & $<0.1$ & $\sim 5000$
\end{tabular}

From a socio-economical point of view, Ios Island is a site in the Aegean sea with untouched natural environment and touristic activity, however only during summer. Hence, possible exploration and exploitation of its quartz deposits will expand the local economic activities during the whole year period and increase the competitiveness of the area by creating new jobs, given that raw materials are fundamental and essential to the economy and improvement of quality of life [20]. On the other hand, safe deposit developments with respect to the environment are not expected to affect the touristic sites in the region from noise, dust or any other influence, as these deposits are situated in the mountainous part of the island and potential future exploitation should take place in specified mining area-district far from any touristic installations.

Certainly, the economic potential of the aforementioned quartz deposits depends on the volume of these deposits. It should be noted here that around the Position 4 area there had already been an exploration field in the late 1950s for exploitation of quartz intended for common (regular) uses in the era. This deposit was estimated to about 50,000 tons of quartz mineral. However, our research is still in its basic stage and quantitative evaluation of the deposits has not been clearly made so far.

\section{Conclusions}

By using XRD in combination with SEM-EDS analysis the quartz samples obtained from new deposits in a relatively small Greek Aegean island, Ios, with almost untouched nature, were identified and thoroughly characterized. The deposits examined contain high-purity $\alpha$-quartz possible to be utilized in the industry of ultra-high purity quartz for specific applications. The low concentration levels of selected trace elements detected using ICP-MS techniques enhance the possibility of industrial exploitation of the deposits detected as quartz lenses in the central and south-western mountainous part of the island in different rock-types within a gneiss-complex of quartz-albite gneiss and garnet-mica schist as well in metamorphosed intrusive bodies. Detailed studies of the geological setting of this area are underway aiming at the determination of the amount of the exploitable quartz. Except of the size and the quality of the quartz occurrences compared to the present quartz industrial demand and the economic benefits of the exploitation, two important issues are additionally under investigation. Namely, i) the balance between the benefits of the expected local economic development of the above area and the efforts to avoid any environmental impact, and also ii) any site contamination, will be decisive factors for potential exploitation of these quartz deposits.

\section{Acknowledgement}

The authors would like to thank the Specific-Account Research Committee of the University of Western Macedonia, Greece for financing the research work presented here under the research grant 80161 (ELKE-TEIWM). 


\section{References}

[1] Keiser, L. J., Soreghan, G. S., Kowalewski, M. (2015). Use of Quartz Microtextural Analysis To Assess Possible Proglacial Deposition For the Pennsylvanian-Permian Cutler Formation (Colorado, U.S.A.). Journal of Sedimentary Research, 85 (11), 1310-1322. doi: https://doi.org/10.2110/jsr.2015.81

[2] Maneta, V., Voudouris, P. (2017). Quartz megacrysts in greece: mineralogy and environment of formation. Bulletin of the Geological Society of Greece, 43 (2), 685. doi: https://doi.org/10.12681/bgsg.11231

[3] Rykart, R. (1995). Quarz-Monographie. Thun, Ott-Verlag, 461.

[4] Dibble, H. L. (2002). Quartz: An Introduction to Crystalline quartz. Dibble Trust Fund Publ., NY USA, 100.

[5] Pe-Piper, G., Piper, D. J. W. (2002). The Igneous Rocks of Greece. The anatomy of an orogeny. Stuttgart: Gebrder Borntraeger, 573.

[6] Arvanitidis, N., Chapman, C., Erausquin, L. A., Kaklamanis, N., Lekatou, A., Panou, G., Platias, S. (2000). New Industrial Applications of quartz vein deposit in Northern Greece. 3th Conference of Mineral Wealth, 1, 59-67.

[7] Platias, S., Vatalis, K. I., Charalampides, G. (2014). Suitability of Quartz Sands for Different Industrial Applications. Procedia Economics and Finance, 14, 491-498. doi: https://doi.org/10.1016/s2212-5671(14)00738-2

[8] Vatalis, K. I., Charalampides, G., Platias, S., Benetis, N. P. (2014). Market Developments and Industrial Innovative Applications of High Purity Quartz Refines. Procedia Economics and Finance, 14, 624-633. doi: https://oi.org/10.1016/s22125671(14)00751-5

[9] Vatalis, K. I., Charalambides, G., Benetis, N. P. (2015). Market of High Purity Quartz Innovative Applications. Procedia Economics and Finance, 24, 734-742. doi: https://doi.org/10.1016/s2212-5671(15)00688-7

[10] Arvanitidis, N. (1997). Vein Quartz Deposits of Northern Greece - Exploitable Resources for Industrial Uses. Mineral Deposits. Balkema, Rotterdam.

[11] Arvanitidis, N. (1998). Northern Greece's industrial minerals: Production and environmental technology developments. Journal of Geochemical Exploration, 62 (1-3), 217-227. doi: https://oi.org/10.1016/s0375-6742(97)00060-5

[12] Kaklamanis, N. (2008). Industrial Minerals, Innovative Technologies, New Products. IGME, Athens, 1-109.

[13] Papadopoulos, P., Anastasiadis, I. (1998). Report of Ore Deposits of Quartz veins - siliconized zones of Korifoula - Leptokarya area of Evros. IGME, Greece.

[14] Orykta (Minerals). Available at: http://www.orykta.gr/oryktes-protes-yles-tis-ellados/latomika-orykta/bio\%20mihanikaorykta/63-xalazias

[15] Spiliotis, X., Karayannis, V., Lamprakopoulos, S., Ntampegliotis, K., Papapolymerou, G. (2020). Synthesis and characterization of greener ceramic materials with lower thermal conductivity using olive mill solid byproduct. EUREKA: Physics and Engineering, 1, 96-106. doi: https://doi.org/10.21303/2461-4262.2020.001116

[16] Damman, H., Kars, S. M., Touret, J. L. R., Rieffe, E. C., Kramer, J. A. L. M., Vis, R. D., Pintea, I. (1996). PIXE and SEM analyses of fluid inclusions in quartz crystals from the K-alteration zone of the Rosia Poieni porphyry-Cu deposit, Apuseni Mountains, Rumania. European Journal of Mineralogy, 8 (5), 1081-1096. doi: https://doi.org/10.1127/ejm/8/5/1081

[17] Naka, H., Kurayasu, H. (1993). Determination of Trace Impurities in High-purity Quartz by Inductively Coupled Plasma Mass Spectrometry. ISIJ International, 33 (12), 1252-1256. doi: https://doi.org/10.2355/isijinternational.33.1252

[18] Götze, J., Möckel, R. (Eds.) (2012). Quartz: Deposits, Mineralogy and Analytics. Springer-Verlag Berlin Heidelberg, 360. doi: http://doi.org/10.1007/978-3-642-22161-3

[19] Platias, S., Vatalis, K. I., Charalabidis, G. (2013). Innovative Processing Techniques for the Production of a Critical Raw Material the High Purity Quartz. Procedia Economics and Finance, 5, 597-604. doi: https://doi.org/10.1016/s2212-5671(13)00070-1

[20] De Vivo, B., Lima, A., Ni, P., Cicchella, D. (2018). Introduction to the thematic issue: mineral deposits exploration and environmental geochemistry: case studies in Italy and in China. Geochemistry: Exploration, Environment, Analysis, 18 (4), $277-277$. doi: https://doi.org/10.1144/geochem2018-060 